\title{
Skin Response Elapsed Time
}

National Cancer Institute

\section{Source}

National Cancer Institute. Skin Response Elapsed Time. NCI Thesaurus. Code C117696.

The interval between two skin response reference time points. 